\title{
Perceptions of the National Credit Regulator on the usefulness of the debt counselling process in
} South Africa

\author{
KH Masilo \\ Tshwane University of Technology, Pretoria, Republic of South Africa \\ masilokh@tut.ac.za
}

\begin{abstract}
The South African National Credit Regulator is responsible for the regulation of credit industry, registration and training of debt counsellors, enforcement and monitoring compliance of the provisions of the National Credit Act. The aim of this paper is therefore to analyse the perceptions of the National Credit Regulator on the usefulness of debt counselling process in South Africa. A qualitative approach, which was exploratory in nature, was adopted for this study. Ten employees from the National Credit Regulator's office were interviewed. There was no evidence that debt counsellors were managing the debt counselling service effectively. It was also observed that the debt counsellors received insufficient support from the National Credit Regulator. The paper recommends that the National Credit Regulator should adequately support the debt counsellors so that they can effectively manage debt counselling service and ultimately assist the overindebted consumers. Debt counsellors training curriculum should also be outcomes- based approach with exposure to business management.
\end{abstract}

Keywords: Debt counselling process, debt counselling course, National Credit Act, National Credit Regulator, South Africa

\section{Introduction}

The expansion of consumer credit in South Africa started to be noticeable since 1968 and has been going on over the past years. According to Prinsloo (2002), from 1985, the importance of consumer credit changed substantially as several factors such as the high level of nominal interest rates, the depreciation in the value of the rand and adverse socio-political developments impacted negatively on consumer confidence and caused a slowdown in the expansion of consumer credit. Prinsloo (2002) further added that the net result of these developments was an increase in mortgage debt relative to total household debt, reaching a level of 53\% in 1988. Excessive interest rates paid by borrowers have caused heinous socio-economic hardships and sufferings for low-income individuals and communities (Du Plessis, 2007). A high percentage of personal income is used to service micro-lending debt, leaving very little of borrowers' personal income to pay for other household expenses (Republic of South Africa, 2006). In addressing this problem, the government introduced the National Credit Act (NCA) No 34 of 2005. The main objective of the NCA is to promote a fair and non-discriminatory marketplace for access to consumer credit and to provide for the general regulation of the consumer credit (Republic of South Africa, 2006).

In support of the objectives of the NCA, the National Credit Regulator (NCR) was established in 2006 and it was tasked with the regulation of the South African credit industry. The main responsibilities of the NCR included carrying out education and awareness of the NCA; consumer protection; registration and monitoring of credit providers, credit bureaus and debt counsellors; receiving and investigating complaints of the consumers and ensuring that consumer rights are protected. This paper aims to analyse the perceptions of the National Credit Regulator on the usefulness of debt counselling process in South Africa. The research focused mainly on the analysis of the reflections of the NCR's perception about the debt counsellors' practices. The rest of the paper covers the literature reviewed, research methodology, findings and conclusions, recommendations, and the limitations of the study.

\section{Literature Review}

The National Credit Regulator was established following the introduction of the National Credit Act No. 34 of 2005 (NCA) and it is responsible for the regulation of the South African credit industry. It is an independent juristic body that is subjected to the South African Constitution and the NCA (Debt Counselling Help South Africa, 2009). Currently it (NCR) has only one main office, which is located in Midrand, Gauteng Province in South Africa. The NCR is tasked with carrying out education and creating awareness of the NCA, which 
includes conducting research about the credit market and monitoring access and the cost of credit in order to identify factors that may undermine access to credit (Republic of South Africa, 2006). NCR is also responsible for competitiveness and consumer protection; policy development; registration, training and monitoring of credit providers, credit bureaus and debt counsellors. In addition the NCR is tasked with regulating, receiving and investigating complaints of both the debt counsellors and the consumers and ensuring that consumer rights are protected.

It is also required that the NCR investigates reckless lending, all alleged contraventions of the NCA and the conduct by any of the registrants (debt counsellors, credit providers and credit bureaus) and to refer unresolved matters to an Ombud with jurisdiction if necessary (Debt free magazine, 2016). Debt counselling was introduced in 2007 to provide a definite process for helping consumers who are encountering problems with their debt repayment (NCR, 2010). It provides a consistent system of debt restructuring, enforcement and judgment, which places priority on the eventual satisfaction of the consumer's obligations under the credit agreements (De Wet, 2011:1-2). A consumer who is experiencing debt repayment problems may seek debt restructuring assistance by applying for debt counselling service at any debt counsellor of his or her choice (Debt Counselling Help South Africa, 2009).

Before debt counsellors begin their operations, they are required to undergo a two-week training approved by NCR (Vessio, 2008) and to register with the NCR. According to Sigamoney, Linganiso \& Karodia (2014), training provides skills and confidence to perform tasks and as such trained debt counsellors will be in a better position to understand their responsibilities. The debt counselling training comprises of the following:

- Purpose and elements of the National Credit Act

- All credit related Acts

- Consumer rights

- Reckless credit and its consequences

- Role of debt counselor

- Debt counseling process

- $\quad$ Compliance with the NCA

- Business ethics

- Role of the NCR (Summitfin, 2014).

Since its inception, debt counselling process has been plagued with challenges and obstacles. The challenges differ in terms of the capacity of debt counsellors and the levels of satisfaction of the stakeholders Groenewald (2010). In assessing the preparedness of the debt counsellors before they start with debt counselling process, Groenewald (2010) launched an intensive study to determine the competency requirements and the skills needed for the debt counsellors. The findings revealed that some debt counsellors were incompetent. They lacked integrity and knowledge of financial management as well as knowledge of credit legislation. The current levels of competencies of debt counsellors; education; expensive legal fees; poor cooperation between credit providers and debt counsellor; and experience in the debt counselling service have been identified as some of the barriers for effective debt counselling process and as such most debt counsellors are no longer practising (Fin24.com, 2013). Masilo (2014) alluded that many debt counsellors trained and registered by the NCR were no longer practicing because they believed that the debt counselling was not financially feasible. The report by the Trade and Industry (Dti, 2013) indicated that by the end of 2013, a total of 2013 debt counsellors were registered with the NCR in South Africa, however, not all of them were practicing. The report further indicated that South Africa had a total of 422624 consumers who applied for debt counselling in 2013 (Dti, 2013).

In an effort to provide guidance and support and as part of its mandate to support and promote debt counselling, the NCR conducted 573 monitoring exercise road shows during 2012/2013 financial year (NCR, 2013). The purpose for the monitoring was to assess compliance with the NCA. In addition Dti (2013) indicated that NCR conducted only six provincial debt counselling workshops or road shows in Gauteng, Eastern Cape, Free State, KwaZulu- Natal, Limpopo and North West. Subsequent to the road shows conducted, Fin24.com (2013) confirms that the registration of two debt counsellors were cancelled by NCR after an investigation into their activities and levels of compliance to the NCA proved to be irregular. In assessing debt 
counselling processes in South Africa, Business Enterprise -UP (2012) conducted a survey and revealed that the two week course that debt counsellors undergo, is only based on the theoretical issues of debt counselling, and does not empower debt counsellors to deal with complex administrative tasks; management of the consumer's file and management of consumers with financial difficulties. In addition, the debt counsellors' lack of commitment and understanding or knowledge about the process and credit were also indicated as a challenge (Business Enterprise - UP, 2012). In 2014, Masilo conducted a study to determine the debt counsellors' level of preparedness and experiences they had with the regulation and monitoring by the National Credit Regulator. The findings revealed that some debt counsellors were incompetent and lacked integrity and ability to interpret the NCA (Masilo, 2014).

According to Masilo (2014), debt counsellors were also aware and expecting that the National Credit Regulator has to ensure and monitor their performances. By monitoring the debt counselling processes, the National Credit Regulator would be able to identify areas of non-compliance and to provide support to the debt counsellors. When non-compliance is identified, such cases should be escalated to the National Credit Regulator's investigations department for an investigation in order to prosecute (Masilo, 2014). The survey used open-ended questions which allowed for multiple responses, and as many as twelve (12) experiences were shared (quoted verbatim) by the debt counsellors as listed below:

- The NCR takes a long time to process transfers of consumers from one debt counselor to another;

- The service they receive from NCR staff is sometimes poor;

- There is no uniformity in terms of how the Magistrate courts operate, they operate differently from one court to the other;

- Poor co-operation between debt counselors and credit providers;

- The NCR dictates how debt counselors should run their businesses;

- Clients struggle to receive clearance certificates because they still have home loans;

- Lack of debt counseling information and education;

- The NCA is unjust to debt counselors, credit providers do not comply but nothing is done;

- Insufficient monitoring by the NCR;

- Lack of NCR's involvement in attending to problems with certain credit providers;

- Insufficient support in terms of problems and queries that they raise with the NCR; and

- Credit Industry Code of Conduct created uncertainty for debt counselors (Masilo, 2014).

Some of the examples of the incompetency of the NCR are highlighted by the South African media. The following are some of the reported examples:

- The NCR had to answer questions before the members of the South African Parliament portfolio committee over the perception that it was not doing enough to bring the transgressors of the NCA to book (Arde, 2016).

- According to (Arde, 2006), the Summit Financial Partners (The Summit) filed a complaint with the South African Public Protector against the NCR. The Summit indicated that the NCR has failed to promote and support the development of effective and accessible credit market as mandated by the NCA.

- In addition, the NCR admitted that it was aware of the misconduct by African Bank, and took no action, despite numerous complaints by consumers and the debt counselors. Action was only taken after the African Bank disclosed and admitted to breach of the NCA. The contravention of the NCA by the bank started in 2011 and it stopped to operate in 2014 (Debt free magazine, 2016).

It is indicative from the above findings and reports that debt counselling faces challenges regarding: inadequate training of debt counsellors; poor cooperation by the credit providers; inability to interpret the NCA, insufficient monitoring, regulation and support from the National Credit Regulator as mandated by the National Credit Act.

\section{Methodology}

This investigation is qualitative (Gummesson, 1988) and has focused on the National Credit Regulator's perceptions on the debt counselling process in South Africa. The research approach adopted in this study 
followed purposive interviews with all ten officials in the debt counselling department from the NCR's offices in Midrand, Gauteng Province in South Africa. These interviews were conducted in one day. According to the analyses, and also following Klein's, (2007) paradigm on investigative interview questions, the questions for the interviews for the ten employees of the NCR were similar and, the responses were also identical with just a few differences. The investigation exposed various causes of the debt counsellors' incompetency and the challenges that debt counsellors face. In highlighting the problem and arriving at the findings, the outcomes emerging from the interviews were then contextualized with the argument to this paper through literature review (Gainer and Padanyi, 2005).

Research Approach: The qualitative approach was adopted mainly to investigate the perception of the NCR on debt counselling process. The interview questions revolved around debt counselling objective and applications; qualifications and prerequisite for a person to become a debt counsellor; effectiveness of debt counselling, interventions and support that NCR gives to the debt counsellors. After the interviews with the employees, the responses, as indicated, were analysed (Griffin and Roberts, 1999). Responses which were analysed to have been similar are reflected with some differences in the findings. It is these differences upon which the brief report that follow is based. These are taken as the reflection of the National Credit Regulator's perceptions on the debt counselling processes.

\section{Reflections from the NCR}

When asked about the purpose or objective of introducing debt counselling, the following emerged:

The objective was to assist over-indebted consumers. Before debt counselling, there were two remedies that is; administration and sequestration measures which had limitations, and were also not effective to assist consumers.

When asked how many debt counsellors were registered and still practicing the following emerged: Records indicate that there are 2013 registered debt counsellors, but not all of them are practicing. There has been a decline in terms of numbers of applications for debt counselling also.

\section{Asked about the qualifications and the prerequisites of debt counsellors, they said:}

For a person to be registered as a debt counsellor, one needs to possess a minimum of a matric qualification. In addition, the person must attend a two-week debt counselling course which is offered by the National Credit Regulator.

When asked if debt counselling is known to consumers, they indicated that:

The National Credit Regulator is making sure that it conducts road shows to inform consumers about the services that the debt counsellors are offering. Most road shows are conducted in Gauteng Province.

\section{When asked why road shows are mostly held in Gauteng, they indicated that:}

The National Credit Regulator had joined the Department of Trade and Industry in their outreach initiatives because they were having challenges in reaching out to communities in rural areas. We are now able to reach communities in other provinces.

When asked about any interventions that they put in place to assist debt counsellors in assisting overindebted consumers, this is what they said:

The National Credit Regulator had been collaborating with the South African Police Service (SAPS) and the South African Social Security Agency (SASSA) to monitor illegal credit provision and subsequently illegal credit providers have been arrested.

When asked if NCR has follow-up mechanisms that they use on practices of the debt counsellors, they indicated as follows:

There are mechanisms like the regular visits that the Regulator does. The National Credit Regulator conducts regular workshops for debt counsellors; in addition, regular communiqués to debt counsellors are issued. 
When asked about the other offices they have other than the one in Midrand, Gauteng Province, they said:

Currently, the duties of the National Credit Regulator are only conducted in Gauteng Province. The National Credit Regulator' staff in the company of the Department of Trade and Industry does conducts workshops at various provinces from time to time.

\section{When asked if NCR give support to the debt counsellors, here is what they unwrapped:}

The National Credit Regulator does support debt counsellors by monitoring, holding workshops where various stakeholders are invited.

\section{Findings and conclusion}

The reviews of literature and the purposive interviews have both been described above. What emerged from the descriptions of both phenomena will now be discussed. It was noted that some of the registered debt counsellors have stopped practicing and not many people are applying to become debt counsellors. People need Matric certificate and a two-week debt counsellors' course to be registered as a debt counsellor. Debt counselling service is not effectively performed due to lack of professional integrity, incompetent debt counsellors, and lack of sufficient support from the NCR. The findings pointed out that debt counsellors were not adequately trained; the NCR does not act instantly to complaints raised by debt counsellors; the regulation, monitoring and support from the NCR is insufficient, and as such there is no proper monitoring on the debt counsellors as mandated by the NCA. The visits, road shows and communiques conducted by the NCR are insufficient as they do not reach all debt counsellors across South Africa, particularly in rural areas. Most road shows are conducted in Gauteng Province. Furthermore, NCR takes long in responding to problems and queries raised by debt counsellors against credit providers.

\section{Conclusion and Recommendations}

The main purpose of this paper was to analyze the perception that the National Credit Regulator has on the usefulness of debt counseling process within the South African context. Based on the findings and the conclusions, the paper recommends that the NCR should review the prerequisites for and the qualifications for people to register as debt counselors. In addition, the NCR should in consultation with accredited trainers; upgrade the content of the debt counselors' training manuals. Furthermore, an occupational curriculum for debt counseling profession and the credit industry be designed. This curriculum should mainly focus on the critical competencies for the debt counselors to enable them to perform tasks as required by the NCA. A more outcomes- based approach with exposure to business management may alter the situation. Arrangements can be made with accredited institutions of higher learning that offers business management courses. This will eradicate the registration of incompetent debt counselors. Furthermore, during such training sessions, prospective debt counselors should be subjected to assessment criteria and be granted with either a competent certificate or an advanced certificate prior to their registration.

The NCR should arrange road shows in all provinces to educate consumers about the dangers of incurring unaffordable debts. The NCR should also make consumers aware of the existence of debt counsellors and the services they offer. The NCR should appraise the outstanding performances of various debt counsellors so as to encourage excellence. These performances can be made public on the debt counsellors' regular newsletters in order to motivate other less-performing debt counsellors. South African media can also be used to announce regular outstanding performances of debt counsellors. This will stimulate recognition of debt counsellors and performance will therefore be improved. It is also recommended that NCR should establish and open satellite offices around all nine provinces of South Africa, not only to deal with extensive duties conferred on it by NCA, but also to deal with administrative matters arising in each province, especially in the light of provincial demographic variance. Following from the performance appraisal recommendation, the external monitors who will evaluate and report on the services of the debt counsellors should be appointed. The NCR should also make the reports public, so that each debt counsellor can be aware of how his or her counterparts perform. This would encourage efficient service provision. 
Limitations of the study: Limitations are matters and occurrences that arise in a study and which are not of the researcher's control (Simon \& Goes, 2013). Limitations influence the extent of the study and it also affect the end result and conclusions that the researcher can take.

Population: The study was limited to the National Credit Regulator's staff. Only ten staff members were interviewed.

Reported data: The researcher interviewed NCR staff members and relied on the information gathered. Unfortunately some of the information cannot be verified and it can have elements such as the following:

- Selective memory - remembering or not remembering experiences or events that occurred in the past;

- Attribution - attributing positive events and outcomes about their own services and attributing negative events and outcomes about other stakeholders; and

- Exaggeration of responses.

- The researcher is of the opinion that the findings of this study could be used for further study.

\section{Reference}

Arde, A. (2016). NCR in hot water over enforcement. Retrieved from: https://www.iol.co.za/personalfinance/ncr-in-hot-water-over-enforcement-2004166 [Accessed 8 November 2017].

Arde, A. (2016). Credit regulator to be probed for failing consumers. Retrieved from: https://www.iol.co.za/personal-finance/credit-regulator-to=be-probed- [Accessed 8 November 2017].

Business Enterprises. (2012). An assessment of debt counselling in South Africa. Retrieved from: http://www.ncr.org.za/publications/DC\%20Impact\%20Assessment\%20Report-2012.pdf [Accessed 2 May 2015].

Debt Counselling Help South Africa. (2009). Debt counselling in South Africa. Retrieved from: http:www.debtcounsellinghelpsa.za [Accessed 16 June 2017].

Debt free magazine, (2016). Complaints to the NCR - How they work. Retrieved from: http://debtfreedigi.co.za/complaints-to-the-ncr [Accessed 9 October 2017].

Debt free magazine, (2016). Parliament grill NCR \& NCT Over investigation results. Retrieved from: http://debtfreedigi.co.za/parliament-grill-ncr-nct-over-investigation-results [Accessed 12 November 2017].

De Wet, K. (2011). What is debt counselling? Retrieved from: http://www.callupcontact.com/b/businessprofile/Karlien_De_Wet_Debt_Counselling/495500 [Accessed 10 May 2017].

Du Plessis, M. A. (2007). The National Credit Act: Debt counselling may prove to a risky enterprise. Journal of Juridical Sciences, 32(2), 74-92.

Dti (Department of Trade and Industry). (2013). Credit Amnesty review update and status report on the debt counselling process. Retrieved from: http://www.ncr.org.za/publications [Accessed 19 June 2017].

Fin24.com. (2013). National Credit Regulator drops debt counsellors. Retrieved from: http://www.fin24.com/Debt/News/NCR-drops-debt-counsellors [Accessed 19 June 2017].

Gainer, B. \& Padanyi, P. (2005). The relationship between market-oriented activities and market-oriented culture: Implications for the development of market orientation in non-profit service organizations. Journal of Business Research, 58(6), 854-62.

Griffin, C. M. \& Roberts, L. L. (1999). Creation of a new needs assessment questionnaire. Journal of Social Behaviour and Personality, 15(1), 121-36.

Groenewald, C. (2010). Debt counselling training in need of serious restructuring according to research. Retrieved from: www.compuscanacademy.co.za/press-room/250-debt-counselling-training-in-need [Accessed 20 May 2017].

Gummesson, E. (1988). Qualitative Methods in Management Research: Chartwell-Bratt.

Klein, K. (2007). Group-level measurement, CARMA Presentation.

Masilo, K. H. (2014). The role of debt counselling in the financial well-being of consumers in Gauteng, Pretoria: University of South Africa. 
NCR (National Credit Regulator). (2010). Survey conducted on consumer credit providers. Retrieved from: http://www.qualityliving.co.za/ [Accessed 2 July 2016].

NCR (National Credit Regulator). (2013). Consumer credit market report. Retrieved from: www.ncr.org.za [Accessed 2 April 2017].

Prinsloo, J. W. (2002). Household debt, wealth and savings. Retrieved from: http://wwwapp.reservebank.co.za/internet/Publication.nsf [Accessed 23 June 2017].

Republic of South Africa. (2006). National Credit Act (NCA). Government Gazette, 28619. Pretoria: Government Printers.

Sigamoney, C., Linganiso, X. \& Karodia, A. M. (2014). Assessing the requirements and benefits of debt collector training in South Africa. International Journal of Accounting Research, 12(1), 1-29.

Simon, M. K. \& Goes, J. (2013). Dissertation and scholarly research: Recipes for success. Retrieved from: http://www.dissertationrecipes.com [Accessed 4 February 2014].

Summitfin. (2014). Debt counselling curriculum for debt counselling. Retrieved from: www.summitfin.co.za/_literature_ [Accessed 19 June 2017].

Vessio, M. L. (2008). What does the National Credit Regulator regulate? South African Mercantile Law Journal, (2008)20, 227-242. 